\title{
A Study on the Situation of Pronunciation Instruction in ESL/EFL Classrooms
}

\author{
Abbas Pourhossein Gilakjani \\ Islamic Azad University, Lahijan Branch, Iran \\ English Language Department, Islamic Azad University, Lahijan, Iran \\ Tel: 60-174-181-660Ｅ-mail: abbas.pourhossein@yahoo.com
}

Received: September 4

Accepted: September 14

Published: December 1, 2011

doi:10.5296/jse.v1i1.924

URL: http://dx.doi.org/10.5296/jse.v1i1.924

\begin{abstract}
Speaking a second language involves different skills like grammar, vocabulary, instruction, and so on. Pronunciation is one of the most important skills in English Language Teaching. If speakers have very bad pronunciation, their speech will not be understandable to the listeners. Despite the fact that acquiring pronunciation is so difficult, in many ESL/EFL classrooms, teaching pronunciation is granted the least attention. In this article, the researcher discusses the status of pronunciation teaching from the viewpoint of many English language teachers, researchers, and writers. Firstly, a brief history of teaching pronunciation and factors affecting the learning of pronunciation are discussed. Secondly, the reason of encouraging students to improve their pronunciation and the time of introducing pronunciation will be discussed. Thirdly, the researcher investigates the kind of pronunciation materials and segmental and suprasegmental features. Finally, the article discusses a number of suggestions for teaching pronunciation and indicates that the teaching of pronunciation can be made more effective in the ESL/EFL classrooms.
\end{abstract}

Keywords: Pronunciation, Materials, Segmental, Suprasegmental, Suggestions 


\section{Introduction}

Many learners of English language have major difficulties with English pronunciation even after years of learning the language. This often results in them facing difficulties in areas such as finding employment (Fraser, 2000a). The fault which most severely impairs the communication process in EFL/ESL learners is pronunciation, not vocabulary or grammar (Hinofotis \& Baily, 1980). Davis (1999) stated that an area of concern and one of the top priorities of ESL students after completing elementary English courses is pronunciation. It is important to make a distinction between speaking and pronunciation as it is sometimes wrongly applied interchangeably. Pronunciation is viewed as a sub-skill of speaking. Fraser (2000a) explains that being able to speak English includes a number of sub-skills of which pronunciation is by far the most important (other sub-skills of speaking include vocabulary, grammar, and pragmatics). She argues that "with good pronunciation, a speaker is intelligible despite other errors; with poor pronunciation, understanding a speaker will be very difficult, despite accuracy in other areas" (Fraser, 2000a, p. 7). In spite of its importance, the teaching of pronunciation has been neglected by teachers in the field of English language teaching. The purpose of this article is to review history of pronunciation, factors affecting pronunciation, reasons of using pronunciation, the kind of pronunciation materials, segmental and suprasegmental features in ESL/EFL classrooms in order to remind ESL/EFL teachers to the importance of pronunciation instruction and the serious problems faced by their students.

\section{A brief history of teaching pronunciation}

In the grammar-translation method of the past, pronunciation was almost irrelevant and therefore, seldom taught (Florez, 1998). Then in the 1950s and 1960s, pronunciation took centre-stage with the introduction of the audio-lingual method. This was a method that emphasised the behaviouristic drilling of sound contrasts and word pairs, and the articulation of individual sounds. However, the drawback to this method was the failure to recognise the need to focus on "rhythm and intonation, the construction of useful sentences, or the practice of realistic conversations" (Fraser, 2000a, p. 32). Instead, learners spent hours repeating sounds and sound combinations in the language laboratory. With the development of the communicative method in the 1970s, Fraser (2000a) and Bray (1995) observe that pronunciation was downplayed to disassociate itself with any link to the drilling practices of the audio-lingual method. It appeared to many teachers then that they had to make a choice. They could either teach about "articulatory phonetics, with pictures of the human mouth and tongue in various positions" or they could choose not to offer any "explicit instruction in English phonology at all" (Bray, 1995, p. 2). As a result, there appeared to be no avenue for the teaching of pronunciation within the communicative method. As the communicative method grew popular within many ESL communities, little focus was given to training would-be teachers in the finer points of teaching pronunciation. Fraser (2000a) notes that many ESL teachers today struggle with teaching pronunciation, and conclude that their training gave them an insufficient basis to work from. With the emergence of more holistic, communicative methods and approaches to ESL instruction today, calls are being made for pronunciation to be addressed within the context of real communication. In this respect, Otlowski (1998) argues that ESL students can expect to master the pronunciation of English 
if pronunciation lessons are made an integral part of the oral communication class.

\section{Factors affecting the learning of pronunciation}

In this section, the researcher mentions some of the important factors that affect the learning of pronunciation. They are as follows:

\subsection{Motivation and exposure}

Along with age at acquisition of a language, the learner's motivation for learning the language and the cultural group that the learner identifies and spends time with help determine whether the learner will develop native-like pronunciation. Research has found that having a personal or professional goal for learning English can influence the need and desire for native-like pronunciation (Bernaus, Masgoret, Gardner, \& Reyes, 2004; Gatbonton et al., 2005; Marinova-Todd et al., 2000; Masgoret \& Gardner, 2003). The review by MarinovaTodd et al., (2000) of research on adult acquisition of English concluded that adults can become highly proficient, even native-like, speakers of second languages, especially if motivated to do so. Moyer (2007) found that experience with and positive orientation to the language appears to be important factors in developing native-like pronunciation. In a study of learners of Spanish, Shively (2008) found that accuracy in the production of Spanish is significantly related to age at first exposure to the language, amount of formal instruction in Spanish, residence in a Spanish-speaking country, amount of out-of-class contact with Spanish, and focus on pronunciation in class. Therefore, in addition to focusing on pronunciation and accent in class, teachers will want to encourage learners to speak English outside the classroom and provide them with assignments that structure those interactions.

\subsection{Exposure to Target Language}

When we speak of the exposure that a learner has to the target language, it may come in the form of their current day-to-day life as well as the amount of prior instruction a learner received in the target language. According to the language learning theories, learners acquire language primarily from the input they receive, and they must receive large amounts of comprehensible input before they are required to speak. Adult learners may have little opportunity to surround themselves with the native target language input. Whereas children who are possibly in English-speaking schools for hours during the day, their adult counterparts are likely to live and work in what these theorists call "linguistic ghettos" where they again have little meaningful exposure to the target language thus inhibiting their acquisition. Learning a new language and speaking it is especially difficult for foreign language learners because effective oral communication requires the ability to use the language appropriately in a variety of interactions (Shumin, 1997). Verbal communication also affects the supra-segmental features of speech such as pitch, stress and intonation. Such features are often not learned from reading a textbook or dictionary. Beyond the supra-segmental features, are the non-linguistic elements involved in language such as gestures, body language, and facial expressions that carry so much meaning yet are not learned through explicit instruction, but rather through sheer experience in a language and culture. Due to minimal exposure to the target language and contact with native speakers, 
adult English language learners often do not acquire a native-like level of pronunciation, regarding fluency, control of idiomatic expressions and cultural pragmatics (gestures, body language, and facial expressions) (Shumin, 1997).

\subsection{Attitude}

It seems as though some learners are more adept at acquiring good pronunciation. Even within one homogenous classroom, there is often a large discrepancy among the pronunciation ability of the students. This phenomenon has lead many researchers to study the personal characteristics of the learners that contribute to their success in foreign language acquisition. In a study on pronunciation accuracy of university students studying intermediate Spanish as a foreign language, Elliot (1995) found that subjects' attitude toward acquiring native or near-native pronunciation, as measured by the Pronunciation Attitude Inventory (PAI), was the principal variable in relation to target language pronunciation. In other words, if the students were more concerned about their pronunciation of the target language, they tended to have better pronunciation of the target allophones (Elliot, 1995). According to Elliot (1995) students who were more concerned about their pronunciation had better pronunciation of English as a Second Language. Sparks and Glachow's work (1991) on personality found similar results. They state that students with motivation to learn with positive attitudes towards the target language and its speakers were more successful than were students with less positive attitudes. They refer to Gardner and Lambert's research on motivation wherein two types are highlighted. The first type of motivation is instrumental, which is motivation to learn the L2 for the value of linguistic achievement. Second is integrative motivation, which describes the desire to continue learning about the second language culture. According to Gardner and Lambert students with integrative motivation would be expected to work harder to develop communication skills in the second language because they are more likely than their less interested counterparts to seek out native speakers of the language.

\subsection{Instruction}

Foreign language instruction generally focuses on four main areas of development: listening, speaking reading and writing. Foreign language curricula emphasize pronunciation in the first year of study as it introduces the target language's alphabet and sound system, but rarely continues this focus past the introductory level. Lack of emphasis on pronunciation development may be due to a general lack of fervor on the part of the second language acquisition researchers, second language teachers and students, that pronunciation of a second language is not very important (Elliot, 1995). Furthermore, Pennington (1994) maintains that pronunciation, which is typically viewed as a component of linguistic rather than conversational fluency, is often regarded with little importance in a communicatively oriented classroom (Elliot, 1995). According to Elliot (1995), teachers tend to view pronunciation as the least useful of the basic language skills and therefore they generally sacrifice teaching pronunciation in order to spend valuable class time on other areas of language. Or maybe, teachers feel justified neglecting pronunciation believing that for adult foreign language learners, it is more difficult to attain target language pronunciation skills 
than other facets of second language acquisition. Possibly, teachers just do not have the background or tools to properly teach pronunciation and therefore it is disregarded.

Teachers have taught what they thought was pronunciation via repetition drills on both a discrete word or phrase level, or give the students the rules of pronunciation like the vowel in a CVC pattern, when given an e at the end, says its name. For example, when an $e$ is added to the word bit (CVC) the pronunciation of the "short i", becomes long and therefore "says its name." This type of instruction is meant to help students with decoding words for the purpose of reading, rather than pronunciation. For example, students are rarely given information about the differences between fricatives and non-fricative continuants, or the subtleties between the trilled or flapped $/ \mathrm{r} /$ between Spanish and English (Elliot, 1995). This particular information is often left up to the students to attain on their own. Researchers have explored the question of whether explicit instruction helps these second language learners. Such studies have generated inconsistent results. There is an insignificant relationship between formal pronunciation and students' pronunciation of English as a Second Language (Elliot, 1995). Adults are able to achieve near native fluency and it can be developed in a relatively short time without serious disruption to the second language teaching program with adequate pronunciation instruction (Elliot, 1995). It is necessary to note at this point that even though there seems to be quite a contradiction in the range of results presented, the diversity of those results may be due to the differing designs of the particular experiments. Some pronunciation studies focus specifically on the instruction of suprasegmentals. Derwing, Munro and Wiebe (1997) conducted research in which ESL learners, who had been studying for an average of ten years, participated in a speaking improvement course that focused on the suprasegmental features of pronunciation (e.g. stress, rhythm, intonation). Thirty-seven native listeners transcribed speech samples (true/false sentences) taken at the beginning of a 12-week course in order to assess the learners' intelligibility. Each sample was rated in order of comprehensibility and degree of accentedness. In the end, there was a significant improvement in the intelligibility, and better ratings over time of comprehensibility and accentedness. They showed that long 30 term language learners could alter their pronunciation in a reading task (Derwing \& Rossiter, 2003).

\subsection{Age}

The influence of age on language acquisition and specifically pronunciation may make adults find pronunciation more difficult than children do and that they probably will not achieve native-like pronunciation. According to the "Critical Period Hypothesis" proposed by Lenneberg (1967, cited in Barros, 2003) there is a biological or neurological period, which ends around the age of 12; after this period it becomes extremely difficult to attain the complete mastery of a second language, especially pronunciation. However, the degree of pronunciation accuracy, according to Avery and Ehrlich (1992, cited in Barros, 2003), varies considerably from one individual to another. To them, this discrepancy in pronunciation among adult learners means that ESL classroom time can profitably be devoted to improving students' pronunciation (Gilbert, 2003). 


\subsection{Mother tongue influence}

Avery and Ehrlich (1992, cited in Thanasoulas, 2003) claim that the sound pattern of the learner's first language is transferred into the second language and is likely to cause foreign accents. The mispronunciations of words by nonnative speakers reflect the influence of the sounds, rules, stress, and intonation of their native language. For example, nonnative speakers' production of English rhythm was investigated in several studies (Wenk, 1985). These researchers concluded that the transfer from the learners' native language influenced their production of English-like stress alternation across a phrase. In this respect, Avery and Ehrlich, (cited in Thanasoulas, 2003) point out that the sound system of the native language can influence the learners' pronunciation of a target language in at least three ways. First, when there is a sound in the target language, which is absent from the learners' native sound inventory, or vice versa, learners may not be able to produce or even perceive the sound(s). Second, when the rules of combining sounds into words (i.e., phonotactic constraints/rules) are different in the learners' mother tongue from those of the target language, they cause problems for learners because these rules are language specific as they vary from one language to another. Thirdly, since the rhythm and melody of a language determine its patterns of stress and intonation, learners may transfer these patterns into the target language. In summary, while there are other factors that influence the learner's L2 pronunciation acquisition (Graham, 1994), the factors reviewed above may help ESL/EFL teachers consider what learners from different backgrounds are likely to face when learning English as a second language. These factors would enable the teachers to identify the difficulties in the pronunciation of the target language experienced by non-native speakers in order to help them overcome their foreign accent and consequently improve their pronunciation. In addition, they would also enable teachers to provide efficient pronunciation instruction, and design their teaching methodology according to students' needs.

\section{The reason of encouraging students to improve their pronunciation}

Terrible pronunciation leads to occasional misunderstanding. Therefore, words and sentences must be repeated due to serious errors in pronunciation (still sounds like steel and ship sounds like sheep), word accent (words are frequently accented on the wrong syllable, e.g., "content" meaning "pleased, satisfied" versus "content" "that which is contained"), and sentence pitch (statements have the 'melody' of questions, etc.). This has been indicated in several studies reviewed by Hahn (Thanasoulas, 2003) where it has been shown that non-native like stress may make native speakers process and comprehend non-native speakers' speech with more difficulty. The student needs to know that improving pronunciation may have greater significance and importance as it supports some aspects like listening comprehension, spelling, reading, and grammar (Wong, 1993). For instance, some students often experience problems or confusion of spelling about which vowel (letter) to write in hate, hard, ahead, hall, and hat, or before 1 in bolt or salt. This confusion happens because learners expect to find a one-to-one correspondence between sound and its spelling, and that it originates from misinterpretation of the spelling system, rather than difficulty with the pronunciation of the sounds (Wong, 1993). 
With good and intelligible pronunciation, the students' self-confidence will be increased and this enables them to better understand their instructors, follow the news on TV or the radio more easily, or join in English conversations, class discussions, role-plays, etc. This can be achieved if students know that pronunciation is an important skill of learning a language just like reading and writing, for example. In addition, the students should be taught that there are standard ways of saying the sounds that make up words and groups of words. This means that an English speaker (British, Australian, American, etc.) will make and expect to hear sounds and groups of words in a sentence that fit with any one of the standard varieties of English. Therefore, although there is flexibility in the way a learner can pronounce English, if the students want to be clearly understood when they speak English and if they want to be able to easily understand what others are saying, they should improve their pronunciation. Students need to understand that if their pronunciation is more natural, their listening will improve.

\section{When to introduce pronunciation?}

Teachers should pay enough attention to pronunciation into their classes and make their students aware of the communicative value of, for instance, intonation and placement of emphatic contrastive stress within sentences. Every dialogue, every role-play in speaking, every lexical phrase in grammar or writing, every text in reading that is taught is an opportunity to do this can be introduced with both demonstration and practice of how its intonation contour contributes to its meaning and communicative function within the context. Teachers may encourage students experiment with phrases to see how the meaning changes with different patterns of intonation and emphasis. Teachers may also encourage students to adopt the use of weak forms and stress-timed speech rhythm when they are aware of the communicative value of stressing or not stressing pronouns, prepositions and auxiliaries for a particular communicative purpose.

To do this, in each lesson, for instance, 5-10 minutes on pronunciation practice can be set aside either at the end of the lesson or in the middle of the lesson when a prevailing problem is spotted or dictated by the context of the learning situation. Also, any time and in any class you see a word that ends in a continuant consonant and the next word starts with a vowel like "an eye", use this pair of words to practice linking. This can be planned or spontaneous and be integrated into grammar, reading, speaking or any other class as needed. In grammar activities such as practicing the continuous tense with "always" or the modals must, may, can't + perfect infinitive, the teacher can teach and practice proper English intonation instead of doing them in the traditional way - which are usually read in an indifferent tone (Stapinska $\&$ Smechowska, 1986). For instance, in practicing the continuous tense with "always", the teacher can ask students to imagine that they have worked together in the same group or have been neighbours for a long time. In either case, they have become fed up with one another's habits and begin to complain:

S1: You're always using my pen.

S2: You're always reading a newspaper when there is a lot of work to do. 
Likewise, in practicing the modals must, may, can't + perfect infinitive, the teacher can begin a situation and ask the students to respond spontaneously and naturally, as in the following example:

T: I saw the king in the street.

S1: You can't have seen the king.

S2: You must have been dreaming.

These activities enable the teacher to demonstrate to his students how native speakers would use the relevant aspects of intonation.

Similarly, in any reading class teachers can include some aspects of pronunciation. For example, students can be made aware beforehand of the pronunciation of difficult words and be advised to focus on elements such as certain sounds, syllables, stress, linking, intonation as they read. After the reading, for instance, students can be advised of pronunciation errors they make, and go over them with the teacher. In this way, a reading class can be a great help for students to develop not only reading skills, but also their pronunciation.

\section{What pronunciation materials to work on?}

Teachers should know the important areas of pronunciation. This prioritizing can be the only practical approach. But, what might the priority items be? There is a wide choice of materials designed to give students extra practice in different aspects of pronunciation, from individual phonemes to intonation patterns, but how effective these materials are is open to debate. In this respect, some researchers believe that learning the pronunciation of English does not mean learning how to pronounce the individual vowel and consonant sounds (Wong, 1993), and that teaching phonemes is not enough for intelligibility in communication (Otlowski, 1998). Instead, pronunciation teaching should include supra-segmental processes (e.g., connected speech, rhythm, word stress, intonation, etc.) because of their impact on speech intelligibility (Wennerstrom, 1999). Nevertheless, the majority of students believe that the most helpful and useful area of pronunciation work is training in segmental rather than supra-segmental because the segmental aspects of pronunciation help them improve their pronunciation patterns, enhance their confidence in using English, and above all they are more easily modified than the supra-segmental aspects (Rajadurai, 2001).

Sounds and words may come before connected speech if there are crucial problems caused by mother tongue interference that affect intelligibility. If this is the case, it should be possible to identify those vowel, consonant and diphthong sounds that cause particular problems to the students. The teacher should know that students may waste time practicing the pronunciation of individual English sounds (phonemes) that they are able to pronounce anyway as these phonemes have similar equivalents in their mother tongue. On the other hand, it is important to note that there are other phonological distinctions which do not involve individual sounds. For example, stress can be distinctive in English, as 'import, being a noun, has a slightly different meaning from im'port, which is a verb. The difference in meaning is indicated by a difference in stress. There are many other pairs like this. Similarly, intonation patterns may 
serve to indicate differences in meaning. "He's coming" said with a rising intonation is a question and thus differs in meaning from "he's coming" said with a falling intonation, which is a statement. The difference in meaning is signalled by the difference in intonation. Therefore, other areas of pronunciation such as communicative problem solving strategies (e.g., asking for repetition and clarification, asking for or giving a synonym, etc.), use of stress and intonation for communicative effect, use of weak forms and variation of speech rhythm to reflect the stress timing of English, and awareness of lexical stress patterns should be integrated and combined with other communicative activities such as grammar and vocabulary (Bell, 2003).

\section{Segmental and suprasegmental features}

Florez (1998) defines segmentals as the basic inventory of distinctive sounds and the way that they combine to form a spoken language. She notes that pronunciation instruction has often concentrated on the mastery of segmentals through discrimination and production of target sounds via drills. Supra-segmentals on the other hand, transcend the level of individual sound production, extend across segmentals and are often produced unconsciously by native speakers (Florez, 1998). Hall (1997) contends that one cannot deny the importance of phonemic discrimination but goes on to cite several researchers who contend that supra-segmental features such as stress, rhythm and intonation are if anything, more important than segmental features. Wong (1993) reminds us that the most relevant features of pronunciation - stress, rhythm, and intonation - play a greater role in English communication than the individual sounds themselves. Suprasegmentals include the following:

Stress - a combination of length, loudness, and pitch applied to syllables in a word

Rhythm - the regular patterned beat of stressed and unstressed syllables and pauses

Adjustments in connected speech-modifications of sounds within and between words in streams of speech

Prominence -speaker's act of highlighting words to emphasise meaning or intent

Intonation - the rising and falling of voice pitch across phrases and sentences

McCarthy (1991) observes that pronunciation teaching in the past has drawn on the works of linguists who have been able to segment the sounds of language into discrete items called phonemes" which, when used in constructing words, "produce meaningful contrasts with other words. Fraser (2000a, p. 11) describes it as "unfortunate" when segmental and suprasegmental features of pronunciation are separated and cautions that it is not the way to go when taking a communicative approach to teaching pronunciation. Hall (1997) stated that Japanese learners benefited from suprasegmental practice through "marking texts for thought groups, shifting emphasis in sentences, and changing the moods of scripts by exploring different intonational patterns." Lambacher $(1999$, p. 138) adds to this point and submits that with communicative ability (and not native-like pronunciation) as the main goal of learning, "the prevailing view is that improvement in the prosodic features has a closer correlation with improved intelligibility of L2 learners." 


\section{ESL/EFL learners' problems in learning pronunciation}

Review of related literature presented in this article was aimed at connecting research findings with ESL/EFL learners' problems toward pronunciation. In this section, I want to mention some of the major problems ESL/EFL learners faced with pronunciation learning. The serious difficulties faced by learners in ESL/EFL classrooms are: lack of motivation, lack of exposure to the target language, not having good attitude towards pronunciation, lack of emphasis on pronunciation by teachers, lack of necessary tools to teach pronunciation by teachers, the influence of sounds and rules of learners' first language on the second language, learners' problems in English spelling systems, lack of enough attention to stress, rhythm, and intonation.

\section{Suggestions for teaching pronunciation}

In looking at recommendations for teaching pronunciation, the researcher describes them within the context of the communicative method of teaching English that is employed in most ESL/EFL classrooms.

\subsection{Curriculum design}

Referring to curriculum and syllabus designs, Morley (1998) submits that English language programs should start by "establishing long range oral communication goals and objectives" that help identify pronunciation needs as well as speech functions and the contexts in which they might occur. Florez (1998) adds that these goals and objectives should be realistic, aiming for functional intelligibility (ability to make oneself relatively easily understood), functional communicability (ability to meet the communication needs one faces), and enhanced confidence in use and they should be the result of a careful analysis and description of the learners' needs.

\subsection{Focus on the suprasegmentals}

Bray (1995) observes that beginning in the late 1970s, several teachers/theorists took a stand by suggesting that at a very basic level if communicative competence was the goal of language learning, then it would have as one of its essential components, intelligible pronunciation. Intelligibility rather than the native-like competence valued in traditional approaches became the goal of phonological instruction. Therefore, teaching speech from the perspective of suprasegmentals seems indispensable within the communicative approach to teaching ESL. However, Bray (1995, p. 3) adds that although many theorists began to make a case for the role of suprasegmental phonology in communication on paper, "many teachers continue with a limited conception of the role of explicit phonological instruction in the language classroom." We can say that curriculum and syllabus designers need to focus on the suprasegmental features of pronunciation. In making their case for emphasis in teaching rhythm to ESL learners in China for example, Chen et al., (1996) discovered that Chinese students were not aware of the difference between the rhythm of the syllable-timed Chinese language and the stress timed English language and therefore drawing their attention to this suprasegmental feature helped significantly in improving their communicative ability. 


\subsection{Academic research and classroom experiments}

Fraser $(2000 b$, p. 5) notes that there is currently "a dearth of reliable research-based information about what works and what doesn't in pronunciation teaching." She adds that there is a need to increase the amount of academic research on these topics, as well as to "increase the research orientation of teachers, and their opportunities to contribute to serious research because teachers are in a position to provide essential information to linguistics." One particular area that needs attention is in the area of assessing ESL/EFL pronunciation. Without reliable assessment and diagnosis tools, it is very hard to quantify the effectiveness of methods or materials and get beyond opinion-based debate. Teachers are always experimenting with a variety of teaching methods and adapt, improvise and even improve on previous techniques. This tradition has to continue especially in relation to teaching pronunciation. Methods that have been tried and tested should be converted into research papers that can be shared with others. Through such methods, Bray (1995) for example describes the use of limericks in the English language classrooms and provides an effective technique for using limericks to help address problems related to suprasegmental features such as stressed, unstressed, and stress-timed rhythm. Chen et al., (1996) present several techniques and tools for teaching word rhythm including the use of visual effects for teaching word stress, auditory techniques such as clapping to differentiate between stressed and unstressed syllables, the use of rubber bands as a visual image for length variation in syllables and stress matching games. Makarova (1996) addresses the question of teaching pronunciation to large groups of students when ideally it requires close individual interaction between teacher and students. She contends that it is possible to get feedback from large number of students and enhance student motivation by applying some less traditional techniques like using phoneme cards, pronunciation-based quiz games, utilizing "sign language" and employing materials prepared by students such as tongue twisters and limericks.

\subsection{Methods and materials development}

Fraser (2000a, p. 2) posits that ESL teachers "need to be provided with courses and materials to help them improve their effectiveness in teaching pronunciation." She adds that there is also a need for "high quality, effective materials, especially computer-based materials with audio demonstrations, for learners of ESL pronunciation, both for self-access and for use in classes where the teacher needs support of this kind." Fraser (2000a, p. 34) opines that teacher training and professional development need to take into account "developments in the area of second language phonology driven partly by an interest in psycholinguistics and theory of speech, and partly by a need to know more about how to teach pronunciation to learners of a second language." Teachers need a greater appreciation of the pronunciation difficulties faced by learners of ESL/EFL and the reasons for these difficulties, and a simple framework for understanding the situation of the second language learner. Lambacher (1999, p. 138) notes that research in pronunciation has revealed that "difficult L2 contrasts (not just suprasegmentals) can interfere with intelligibility and a need therefore exists within the pronunciation curriculum to address the problems of L2 learners in identifying and producing difficult L2 speech contrasts." Computer Assisted Instruction (CAI) for pronunciation 
can be an effective tool as it "provides electronic visual feedback (EVF), which can help meet this essential need by showing the exact sound features that learners produce and thereby drawing attention to changes that they need to make" (Lambacher, 1999, p. 138).

\subsection{Teacher training}

Fraser (2002) notes that it is hardly surprising that so many teachers are not confident with teaching pronunciation because training that is available often does not cover the most essential aspects of knowledge about speech and pronunciation relevant to teaching adult English language learners. Most teachers have been equipped with information about English phonemics: the IPA symbols, the articulation of English phonemes and sometimes with some basic English intonation patterns. However, what is much more useful is some understanding of the psycholinguistics of speech perception and production, and the effects of a person's native language and literacy on their interpretation of speech.

\section{Conclusion}

There are many reasons why the teaching of ESL/EFL pronunciation is currently less than optimally effective, and certainly it is wrong to blame anyone group, whether teachers, pronunciation specialists, or academics. Language pronunciation is a topic of great theoretical interest and practical relevance which unfortunately has been out of fashion for some decades. ESL/EFL teachers should focus on the students' needs, level and ability, incorporate pronunciation into their oral skills and other classes and focus on both segmental and supra-segmental features whenever there is opportunity and time. Pronunciation must be viewed as more than correct production of individual sounds or isolated words. Instead, it must be viewed as a crucial and integral part of communication that should be incorporated into classroom activities. Teachers can help students by highlighting elements such as sounds, syllables, stress and intonation. Once the students understand the functions of these elements, they will know what to focus on and can build upon this basic awareness. Teachers can actively encourage the students' actual production, build pronunciation awareness and practice through classes. They can encourage them repeatedly to monitor their own pronunciation and practice their speaking skills as much as possible in and outside the classroom - because changing pronunciation habits is hard work and requires time and effort from the students. They can also improve their self-confidence in daily encounters in and outside the classroom with native (and non-native) speakers by gradually building skills in listening and speaking in both formal and informal situations. It can be concluded that with careful preparation and integration, pronunciation can play an important role in supporting the learners' overall communicative power.

\section{References}

Avery, P., \& Ehrlich S. (1992). Teaching American English Pronunciation. New York, NY: Oxford University Press.

Barros, A. (2003). Pronunciation Difficulties in the Consonant System Experienced by Arabic Speakers When Learning English after the Age of Puberty. Unpublished M.A. Thesis, West Virginia University, 2003. http://etd.wvu.edu/ETDS/E2937/Barros_Ana_Marina_thesis.pdf; 
visited $15,9,2003)$

Bell, M. A. (1996). Teaching Pronunciation and Intonation to EFL Learners in Korea. (http://www.geocities.com/Athens/Acropolis/9583/PRONUN.html; visited, 15, 6, 2003),

Bernaus, M., Masgoret, A., Gardner, R., \& Reyes, E. (2004). Motivation and attitudes towards learning language in multicultural classrooms. International Journal of Multilingualism, 1(2), 75-89. http://dx.doi.org/10.1080/14790710408668180

Bialystok, E., \& Frohlich, M. (1997). Variables of classroom achievement in second language learning. The Modern Language Journal, 4 (7), 327-336.

Bray, E. (1995). Using limericks to help Japanese students improve their pronunciation. Paper presented at the Annual Meeting of the Japanese Association of Language Teachers, Japan, November.

Chen, C. F., Fan, C.Y., \& Lin, H. P. (1996). A New Perspective in Teaching Pronunciation: Rhythm. ERIC Document [ED 397 638]

Davis, C. (1999). Will the use of videos designed for the purpose of teaching English pronunciation improve the learners' production of discrete sounds by at least $80 \%$ over a 12-week period? In Action Research Monographs. Pennsylvania Action Research Network. A Section 353 Project of the Pennsylvania Department of Education, Bureau of Adult Basic and Literacy Education. ERIC Document [ED440 219].

Derwing, T., \& Rossiter, M. (2003). The effects of pronunciation instruction on the accuracy, fluency, and complexity of L2 accented speech. Applied Language Learning, 13 (1), 1-17.

Elliot, A. R. (1995). Field independence/dependence, hemispheric specialization, and attitude in relation to pronunciation accuracy in Spanish as a foreign language. The Modern Language Journal, 79(iii), 356-371. http://dx.doi.org/10.2307/329351

Elliot, A. R. (1995). Foreign Language Phonology: Field independence, attitude, and the success of formal instruction in Spanish pronunciation. The Modern Language Journal, 79(iv), 530-542. http://dx.doi.org/10.2307/330005

Field, J. (2005). Intelligibility and the listener: The role of lexical stress. TESOL Quarterly, 39(3), 399-423. http://dx.doi.org/10.2307/3588487

Florez, M. C. (1998). Improving adult ESL learners' pronunciation skills. ERIC Digest. Retrieved December 12, 2005, from www.cal.org/caela/digests/ Pronun.html.

Fraser, H. (2000a). Coordinating improvements in pronunciation teaching for adult learners of English as a second language. Canberra: DETYA (Australia National Training Authority Adult Literacy Project) Retrieved October 31, 2004, from http://www-personal.une.edu.au/ hfraser/docs/HF_ANTA_REPORT.pdf

Fraser, H. (2000b). Literacy vs oral communication skills for ESL learners. In Literacy Link, Newsletter of the Australian Council for Adult Literacy. 
Fraser, H. (2002). Change, challenge and opportunity in pronunciation and oral communication. Plenary Address at English Australia Conference, Canberra, October 2002. Retrieved December 28, 2006, from http://wwwpersonal. une.edu.au/ hfraser/documents/HFChangeChallengeOpp.pdf.

Gatbonton, E., Trofimovich, P., \& Magid, M. (2005). Learners' ethnic group affiliation and L2 pronunciation accuracy: A sociolinguistic investigation. TESOL Quarterly, 39(3), 489-511. http://dx.doi.org/10.2307/3588491

Gilbert, J. (2003). Slipping Pronunciation into the Regular Class. (http://www.eltnews.com/features/teachingideas/010_1jg.shtml; visited 20,5).

Graham, J. (1994). "Four Strategies to Improve the Speech of Adult Learners." TESOL Journal, 3, No. 3, 26-28.

Hall, S. (1997). Integrating pronunciation for fluency in presentation skills. Paper presented at the Annual Meeting of the Teachers of English to Speakers of Other Languages, Orlando, March 1997. Retrieved October 31, 2004, fro m h t t p: // w w w . pe r s o n a l. u n e . e d u . a u / h fra s e r / d o c s / HFChangeChallengeOpp.pdf

Hinofotis, F., \& Baily, K. (1980). American undergraduate reaction to the communication skills of foreign teaching assistants, TESOL "80: Building Bridges: Research and Practice in TESL", Alexandria, V.A.

Lambacher, S. (1999). A CALL tool for improving second language acquisition of English consonants by Japanese learners. Computer Assisted Language Learning, 12(2):137-156. http://dx.doi.org/10.1076/call.12.2.137.5722

Lenneberg, E. H. (1967). The geological foundations of language. New York: John Wiley and Sons.

Makarova, V. (1996). Teaching English pronunciation to large groups of students: some suggestions. Paper presented at the National Japanese Conference for English Language Education, Japan, August 1996.

Marinova-Todd, S. H., Marshall, D. B., \& Snow, C. E. (2000). Three misconceptions about age and L2 learning. TESOL Quarterly, 34(1), 9-34. http://dx.doi.org/10.2307/3588095

Masgoret, A., \& Gardner, R. (2003). Attitudes, motivation, and second language learning: A meta-analysis of studies conducted by Gardner and associates. Language Learning, 53(Suppl. 2), 167-210. http://dx.doi.org/10.1111/1467-9922.00227

McCarthy, M. (1991). Discourse Analysis for Language Teachers. London: Cambridge University.

Morley, J. (1998). Trippingly on the tongue: Putting serious speech/pronunciation instruction back in the TESOL equation. ESL Magazine, January/February, 20-23. 
Moyer, A. (2007). Do language attitudes determine accent? A study of bilinguals in the USA. Journal of Multilingual and Multicultural Development, 28(6), 502-518. http://dx.doi.org/10.2167/jmmd514.0

Munro, M. J., \& Derwing, T. M. (1999). Foreign accent, comprehensibility, and intelligibility in the speech of second language learners. Language Learning, 49(Suppl. 1), 285-310. http://dx.doi.org/10.1111/0023-8333.49.s1.8

Otlowski, M. (1998). "Pronunciation: What Are the Expectations?" The Internet TESL Journal, IV, No. 1. (http://iteslj.org/Articles/Otlowski-Pronunciation.html; visited, 20, 5, 2003).

Pennington, M. (1994). Recent research in L2 phonology: Implications for practice. In J. Morley, (Ed.) Pronunciation pedagogy and theory. New views, new directions. pp. 92-108. Alexandria, VA: Teachers of English to Speakers of Other Languages. (EDRS No. ED 388 061)

Rajadurai, J. (2001). An Investigation of the Effectiveness of Teaching Pronunciation to Malaysian TESOL Students. Forum, 39, No. 3 (2001), 10-15.

Shively, R. L. (2008). L2 acquisition of $[\beta],[\delta]$, and $[\gamma]$ in Spanish: Impact of experience, linguistic environment and learner variables. Southwest Journal of Linguistics, 27(2), 79-114.

Shumin, K. (1997). Factors to consider: developing adult EFL students' speaking abilities. Forum 25 (3), 8. Somali: A language of Somalia. (n.d.) Ethnologue report for language code; SOM. Retrieved June 10, 2004, from http://www.ethnologue.com/show_language.asp?code=SOM Somalis-Their history and culture (n.d.). Refugee Fact Sheet No. 9. Retrieved February 13, 2006 from www.culturalorientation.net

Sparks, R., \& Ganschow, L. (1991). Foreign language learning differences: Affective or native language aptitude difference? The Modern Language Journal, 75 (1), 3-16. http://dx.doi.org/10.2307/329830

Stapińska, M., \& Śnıechowska, J. (1986). More Effective Grammar Practice. Forum, 24, No. 4, 35-36.

Thanasoulas, D. (2003). Pronunciation: The Cinderella of Language Teaching. (http://www.developingteachers.com/articles_tchtraining/pronpf_dimitrios.htm; visited, 15, $10)$.

Wenk, B. (1985). Speech Rhythms in Second Language Acquisition. Language and Speech, 28, No. 2, 157-175.

Wennerstrom, A. (1999). Why Suprasegmentals? TESOL Matters, (October/November, 20).

Wong, R. (1993). Pronunciation Myths and Facts. Forum, 31, No. 4, 45-46. 